\title{
Understanding the mechanisms of administrative burden through a within-case study of Medicaid expansion implementation
}

\section{Cheryl A. Camillo*}

\begin{abstract}
The importance of the administrative burden problem in public programs has been apparent during the COVID-19 crisis in the United States as millions of newly unemployed people have had to wait for unemployment checks and public health insurance benefits due to paperwork requirements, agency staff shortages, and outdated information technology systems. The resulting burdens have extended financial hardship, caused the coronavirus to spread, and eroded citizen and agency morale. Administrative burdens have long been known to be costly, yet remain fixtures of public benefit programs across the world. To reduce them, we need to understand their mechanisms. Formal policy solutions per se will not reduce administrative burdens because they do not exist solely by design - they are often the product of individual and group politics or the consequence of organizational processes. This article makes a positive contribution to behavioral public administration by providing a comprehensive, empirical-driven theoretical framework for understanding the complex processes through which supply-side administrative burdens are instituted, modified, and eliminated. Using a retrospective within-case study method that utilizes participant observation, documentation, and archival records, the article traces the process by which a state eliminated administrative burdens in the process of implementing an initially straightforward expansion of Medicaid eligibility, thereby creating a model for simplifying and streamlining enrollment that was incorporated into the Affordable Care Act. In addition to the theoretical framework, this article provides actionable tools for policymakers and practitioners to use when formulating and implementing program policy.
\end{abstract}

Keywords: Administrative burdens, Medicaid, Eligibility expansion, Policy implementation, Street-level bureaucracy, Behavioral public administration, Positive public administration

$\mathrm{T}$ he COVID-19 crisis has highlighted the need for public programs to reduce administrative burden, or the experience of policy implementation as onerous (Burden, Canon, Mayer, \& Moynihan, 2012, p. 741; Herd, DeLeire, Harvey, \& Moynihan, 2013, p. S69). During the coronavirus pandemic, Americans who have lost their jobs have had difficulty filing for unemployment insurance, overworked state agency employees have struggled to process their cases, and antiquated information technology systems have failed to detect fraudulent claims (McGreevey \& Christensen, 2020; Pressgrove, 2020). As a result, needy individuals have gone without assistance and organized criminals have defrauded the federal and state governments of hundreds of millions of dollars, among other costs (Baker, 2020; Herd \& Moynihan, 2020).

Although administrative burden has long been considered problematic (Lipsky, 1984; Moynihan, Herd, \& Harvey, 2014; Piven \& Cloward, 1971), efforts to reduce it have been hindered by an insufficient understanding of its causes and mechanisms. Specific origins of burdens, such as bureaucratic disentitlement (1984) and red tape (Bozeman, 1993), have been identified, but theory explaining why they originate and how they intertwine during policymaking and implementation is lacking. In cataloging sources of supply-side (or organizational)

* Graduate School of Public Policy, University of Regina

Address correspondence to Cheryl Camillo at (cheryl.camillo@uregina.ca)

Copyright: (C) 2020. The author licenses this article under the terms of the Creative Commons Attribution 4.0

International License. 
administrative burdens, Peeters (2020) called for empirical-driven causal explanations for their existence (pp. 584-585).

This article presents a retrospective within-case study that tells, from the perspective of the practitionerscholar, the story of why and how the State of Maryland significantly reduced and shifted administrative burdens in its Medicaid program (Cohen Ross \& Marks, 2009, p. 13) while implementing an initially straightforward, stand-alone expansion of income eligibility for families in 2007-2008. In presenting the case, the article provides a comprehensive theoretical framework for understanding the complex and dynamic processes by which supply-side administrative burdens can be imposed, modified, and eliminated through the multi-layered interactions of policymakers, public managers, street-level bureaucrats, and interest groups. This article also provides actionable tools for use in formulating and implementing program policy.

\section{Supply-side Origins of Administrative Burden}

The concept of administrative burden is grounded in the literature on the political-administrative state (Weber, 1946), policymaking (Klarner, Mao, \& Buchanan, 2007; Soss, Schram, Vartanian, \& O'Brien, 2001), and policy implementation (Brodkin \& Majmundar, 2010; Heinrich, 2016; Lipsky, 1984). In democratic states, politically selected officials, after public and private consideration of their options, provide policy directions to bureaucracies and other delegated organizations to implement and administer on an ongoing basis using an array of formal and informal tools.

Administrative burden occurs in all fields in which policies are implemented, but is most commonly examined in the context of public benefit programs, such as health insurance (Herd et al., 2013), in which bureaucrats regularly engage in transactions with individuals, families, or households.

Administrative burden can take many forms, including excessive paperwork or interview requirements. Onerous transactions between citizens and the state are harmful to individuals, institutions, and society. In addition to benefit delays and stressful work conditions like those recently seen in US unemployment insurance programs, burdens can inflict long-term harm on groups by excluding them administratively (Brodkin \& Majmundar, 2010) and diminishing their take-up (Hernanz, Malherbet, \& Pellizzari, 2004), which, in turn, can erode social solidarity.

Most research on administrative burden has focused on its impacts on individuals instead of on its origins. Citing neglect of the "task of providing a theoretical framework for understanding their existence and nature," Peeters recently (2020) furthered the research by reviewing the academic literature on administrative burden and adjacent fields, such as take-up, and identifying the supply-side explanations found within. In an effort to think systematically about burden's origins, he organized the explanations (for example, "internal red tape," "administrative errors," and "street-level coping strategies") into four ideal-type quadrants based on their level of intentionality and degree of formality (p. 582), but acknowledged that his two-dimensional framework was limited because the quadrants are often intertwined in practice (p. 584). Peeters hypothesized that the probability of reducing burdens depends upon their relation to an organization's "political economy of deeply engrained structures and behavioral patterns" (p. 566), their origins in hidden politics, and their appeals to organization or political interests, but he also advocated for empirical research to improve our understanding (pp. 584-585).

This case study responds to the need for practice-informed empirical research on the organizational origins of administrative burden.

\section{Examining the Causes and Mechanisms of Supply-side Administrative Burden through an Implementation Case Study}

A new research paradigm is needed to study organizational administrative burden. Public administration researchers need to focus on the implementation process since program implementation ultimately determines whether and in what form(s) burdens exist (Smeeding, 2019, p. 1077). In analyzing implementation processes, they should draw on insights from political psychology about the behavior of individuals and groups (Grimmelikhuijsen, Jilke, Olsen, \& Tummers, 2016). Furthermore, researchers should be actionable, meaning that 
they should generate knowledge that enables action or intervention in concrete situations (Bartels, 2012, p. 435; Etzioni, 2008, p.833).

According to Beach and Pederson (2013, pp. 1-2), "process-tracing methods are arguably the only method that allows us to study causal mechanisms." They enable the researcher to make strong within-case inferences about causal processes in single case studies and, thus, to build theory regarding causal mechanisms (Rury, 2014). Causal-process tracing "answers 'why' and 'how' questions because it focuses on the causal conditions, configurations and mechanisms which make a specific outcome possible" (Blatter \& Haverland, 2014, p. 1). In Blatter and Haverland's approach, causal-process tracing is based on configurational thinking that assumes: (a) outcomes are the result of a combination of causal factors; (b) there are divergent pathways to similar outcomes; and (c) the effects of the same causal factor can be different in different contexts and combinations (2014, p. 7). The aim of causal-process tracing is to "reveal the sequential and situational interplay between causal conditions and mechanisms in order to show how they generate the outcome of interest" (2014, p. 2), which in this case study was a state Medicaid program's reduction or assumption of administrative burden.

A within-case study was performed to identify how and why Maryland eliminated several burdens to residents and state employees and shifted others while implementing Medical Assistance for Families (MAF), an expansion of Medicaid to low-income working families that was effective July 1, 2008. The case is instrumental (Barzelay, 2007) because MAF subsequently served as a model for the eligibility and enrollment streamlining provisions of the Affordable Care Act of 2010, which all US states were required to implement by 2014 .

The means-tested Medicaid program makes an excellent case for the study of administrative burdens due to its notoriously intricate eligibility rules that present many barriers to application and enrollment (Ravenell, 2003). ${ }^{1}$ Medicaid is a federal-state partnership — each state designs its program within broad federal guidelines. With over 70 million beneficiaries, it is the largest public health insurance program in the US. Medicaid's initial purpose was to increase access to health care for families with deprived, dependent children receiving cash assistance, but the US Congress has gradually extended eligibility to other categories of low-income individuals, including disabled individuals receiving cash assistance and children and pregnant women not receiving cash assistance. States have some flexibility to set the income and asset (if any) thresholds for each category. States must provide a basic package of health care services to Medicaid beneficiaries.

Data sources for this case study were participant observation, documentation, and archival records. "Participant observation is generally associated with ... why questions [and] causal explanations" (Guest, Namey, \& Mitchell, 2013 p. 5). To generate actionable knowledge that is useful to policymakers and implementers, the researcher must be enmeshed in the situation of analysis (Bartels, 2012). In promoting positive public administration, Douglas et al. (2019) proposed giving voice to lived experience. The novelty of this study is that the researcher was the participant-observer who led the implementation of MAF. By taking the roles of observer and observed, the researcher is able to narrate more of the implementation process than a traditional participant-observer would likely have been able to describe given that the lead implementer-turned-researcher had full access to proceedings that are typically limited to select public officials (Etzioni, 2008). ${ }^{2}$ The risk of recall bias (Kim, 2017) or manipulation of events by the participant-observer (Yin, 2009) was minimized by the study's epistemological strategy to identify causal factors, their combinations, and their outcomes within their context. This was done to build a testable theory about causal mechanisms instead of making inferences about other cases based on the MAF case. Nevertheless, the study narrative was corroborated to the extent possible by documents and archival records.

The researcher narrates the MAF case retrospectively from the emic perspective, or insider's point of view (Rury, 2014). After describing the underlying context, the researcher presents the implementation story through a differentiation of the sequence of events ('causal chains') and an identification of the critical junctions ('causal junctions') of selected steps of the process. This is because "spatial contiguity and temporal succession are important epistemological foundations for drawing causal inferences" (Blatter \& Haverland, 2014, p. 8). The researcher notes the most significant individuals and organizations involved at each step and recounts their discussions, sometimes verbatim, in order to enable political psychological analysis of the individual motives and group dynamics that shaped decision-making. 


\section{The Medical Assistance for Families Story: Enabling Effective Expansion by Reducing and Shifting Administrative Burdens}

\section{The Political, Legislative, Bureaucratic, and Policy Context}

In early 2007, up-and-coming Democratic politician Martin O'Malley took office as the new governor of Maryland and began to plot an ambitious agenda to address the state's $\$ 1.7$ billion structural budget deficit while tackling pressing policy issues. ${ }^{3}$ That October, he called a risky, rare special session of the state legislature to enact that agenda, which included tax increases, early in his term (Wagner, 2007).

Making Maryland "a national leader in improving health care" (Sharfstein, Peterson, Brown, Katz, Brown, Lindamood, \& Luckner, 2007) was on O'Malley's agenda and included in the package of bills he pushed was Senate Bill 6: the Working Families and Small Business Health Coverage Act to provide comprehensive health insurance to previously ineligible working parents and their families, including by increasing the Medicaid income standard for low-income families from 37 percent of the Federal Poverty Level (FPL) to 116 percent, thereby progressing from having one of the lowest income standards in to the country to one of the highest (Cohen Ross, Horn, \& Marks, 2008, p. 35). Senate Bill 6 (SB6) was one of three bills passed by the legislature during the special session. It was enacted on November 19, 2007 to be effective "on July 1, 2008 as permitted by federal law and subject to limitations of the state budget" (Working Families and Small Business Health Coverage Act, 2007). The bill stipulated that the expansion, which was later dubbed 'Medical Assistance for Families,' was to be paid for by an assessment on hospitals equal to a reduction in uncompensated care resulting from increased Medicaid enrollment.

At the recommendation of O'Malley's transition team, who was concerned about the state's history of poorly implemented eligibility expansions, the governor authorized the Department of Health and Mental Hygiene $(\mathrm{DHMH})^{4}$, which ran the state Medicaid program, to create a new Office of Eligibility Services (OES) within its Medicaid administration and to appoint "a skilled person ... who could provide vision ... evaluate the shortcomings of the entire eligibility process ... and initiate needed reforms" to direct it at the pleasure of the governor (Sharfstein et al., 2007). The DHMH Medicaid director recruited a researcher from the federal Medicaid office to lead OES and to serve on the program's executive leadership team alongside several longtime DHMH senior employees effective mid-September 2007 (Maryland State Archives, 2020a). The Medicaid director assigned the OES executive director responsibility for leading MAF implementation.

Neither the governor nor the legislature directed changes to Maryland's relatively conservative Medicaid eligibility regime other than the increase in the income standard. Maryland maintained some of the most restrictive eligibility policies for families in the country - it was one of only 11 states to require a face-to-face interview upon application and 29 to impose an asset test (Cohen Ross et al., 2008). In addition, Maryland's Medicaid program relied upon, as it had since the program's inception, the 24 local (county-based) Departments of Social Services (LDSS), working under the jurisdiction of the state Department of Human Resources (DHR) ${ }^{5}$, to determine eligibility for families using DHR's joint Medicaid/welfare/nutrition assistance program paper application (Maryland State Archives, 2020b; Maryland State Archives, 2020c).

\section{Standard Implementation Steps}

Given that Medicaid eligibility is determined prospectively, MAF had to be fully implemented by June 1, 2018, just six months after SB6's enactment. The tasks required to implement the increase in the income threshold for the existing eligibility group were the standard tasks required to operationalize eligibility changes, which included:

- request and receive approval for each policy change from the federal government,

- develop outreach materials and conduct outreach,

- amend state regulations,

- reprogram the automated eligibility system (the Client Automated Resources Eligibility System or CARES),

- revise the desk manual and other guidance used by eligibility caseworkers (street-level bureaucrats), and

- train caseworkers. 
To ensure successful implementation, these tasks needed to follow a certain sequence; for example, CARES programming changes needed to be completed and tested before guidance to caseworkers could be written and delivered.

\section{Medical Assistance for Families Implementation Process}

The OES executive director initially planned to implement only the income eligibility increase, but a chain of events led the executive director to request the Medicaid director's approval to eliminate several administrative burdens that the state was imposing upon applicants and beneficiaries and to shift other burdens to the state. Appendix A lists the actions ultimately taken to relieve burdens. Following is an abridged narrative detailing the key factors and critical moments that prompted the executive director to pursue selected actions.

In OES' first MAF meeting after the enactment of SB6, two senior managers who were supposed to play integral roles in implementation declared their opposition to the eligibility expansion for ideological and workload reasons. Early one December morning, the manager of one of the LDSS offices disregarded the wellestablished chain of command and phoned the OES executive director's desk line to vent about queues of anxious applicants snaking around the building, thus signaling the onset of the Great Recession and a sharp rise in Medicaid applications. Due to the deep recession, in the first months of 2008 the governor's office twice ordered the Medicaid program to make large cuts to its budget, including by eliminating positions and leaving vacant positions unfilled. Given that the state was cutting positions, the state Department of Budget and Management decided to allocate only a dozen new positions to process the projected 30,000 new MAF cases. This combination of events led the executive director to conclude that MAF implementation would be a fiasco unless the state lightened the workload of frontline managers and Medicaid eligibility workers. The executive director anticipated that street-level bureaucrats would engage in behavioral coping strategies against clients, such as rationing, if their caseloads grew any larger (Tummers, Bekkers, Vink, \& Musheno, 2015), or would make a lot of errors prompting federal scrutiny.

To facilitate decision-making about reducing or shifting burdens, the executive director developed two decision aids - a model showing the main steps of the eligibility process (Figure 1) and a table (Appendix B) describing the types of burden that could be imposed upon residents during the process.

\section{Figure 1. Model of Administrative Burdens in Receipt of Program Benefits}

Demand-side

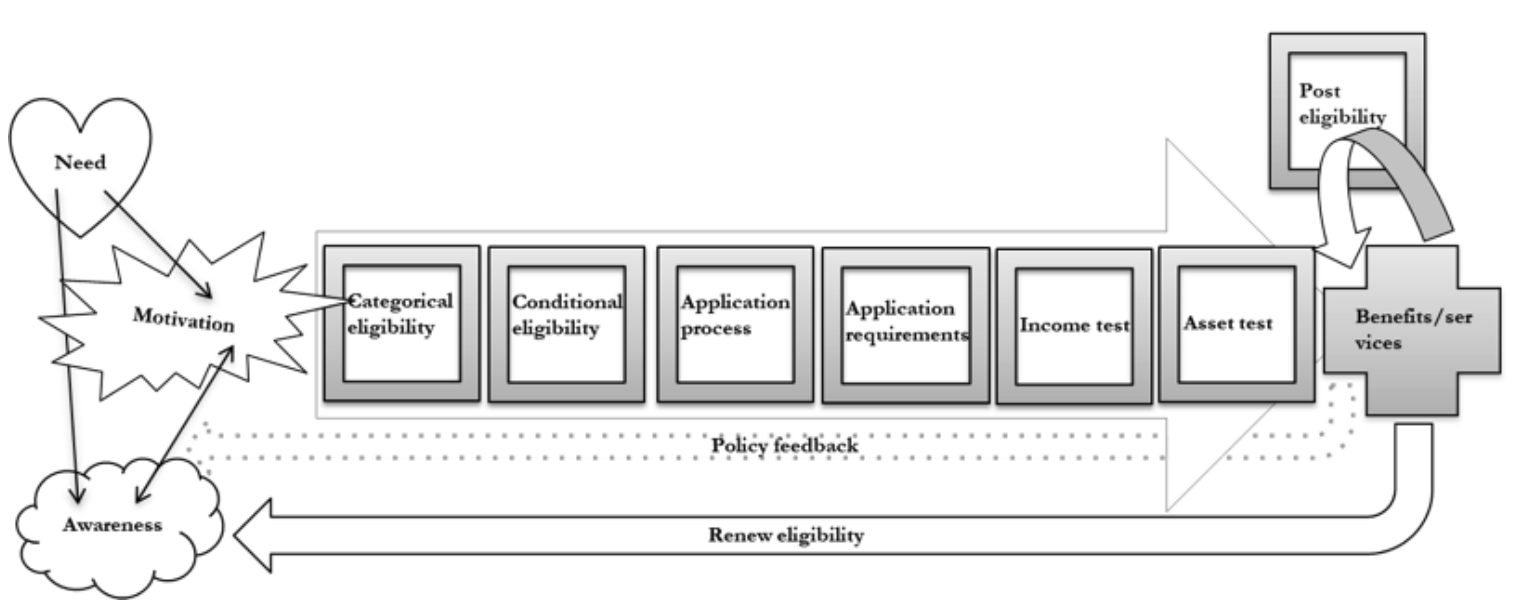


One winter day, despite the budget crisis, the DHMH chief of staff visited the weekly Medicaid management meeting to appeal for cutting edge outreach strategies to promote MAF as part of two high profile national initiatives it had received competitive grant funding (Robert Wood Johnson Foundation, 2020) for in partnership with Maryland Health Care for All!, the state's largest and most powerful consumer coalition, and Johns Hopkins University, the operator of the state's largest health system (and the largest provider of health services to Medicaid beneficiaries). In lobbying for SB6, the governor's office had cited an enrollment goal and it was intent on achieving it. Also in the winter, upon OES' submission of the CARES programming request, DHR, the system's owner and employer of the programming staff, told OES staff that MAF was low on its long priority list and that the programming would not be finished before July. ${ }^{6}$ Seeking to satisfy the chief of staff's request for an innovative outreach plan, to leverage the grant funding in a period of scarcity, and to streamline enrollment processes so that caseworkers could make eligibility determinations within the federally-mandated 45-day time limit, the executive director proposed that the state identify and enroll eligible, uninsured families through state income tax returns; auto-enroll beneficiaries (rather than wait for them to apply) in the limited benefit 'medically needy' eligibility category and Primary Adult Care program who would newly qualify for Medicaid due to the increase in the income standard; and use some grant funding to hold a process improvement collaborative with frontline workers from all eligibility offices to develop ideas to streamline MAF application processes.

After approaching the Secretary of DHMH at the Maryland State House during the regular 2008 state legislative session 7 , the board of the Maryland Women's Coalition for Health Care Reform met with Medicaid staff at DHMH headquarters to request that the program eliminate organizational administrative burdens in the application and renewal process. Upon consulting the decision aids (Figure 1 and Appendix B) and OES staff, the executive director moved to eliminate the face-to-face interview requirement, most verification requirements, and the asset test. Based on the experiences of OES managers who had been caseworkers, the executive director concluded that eliminating a single barrier in the application process, such as the interview, would not be impactful, but eliminating multiple barriers would. Eliminating multiple burdens would not bring more applicants to Medicaid's door, but would increase the number of successful applicants. It would also streamline application processing. Given that eliminating each barrier entailed the same tasks-revise regulations, write guidance, and provide training - it did not significantly increase the implementation workload to eliminate them simultaneously.

During a telling telephone conversation about implementation progress, the executive director's DHR counterpart declared with exasperation, "We believe families need food before health insurance!" 8 Not long thereafter, in the executive director's quarterly meeting with LDSS managers, they complained about caseloads and hinted that they were out of compliance with federal regulations for determining Medicaid eligibility for disabled individuals. Around that time, legal aid attorneys sued DHMH and DHR for the LDSS' failure to determine eligibility for the disabled in a timely fashion. Meanwhile, the county health officers, who reported to DHMH, requested that the LHDs, which determined Medicaid eligibility for pregnant women and children, also determine MAF eligibility. The executive director's most influential peer on the Medicaid leadership team energetically backed that request. Authorizing LHDs to determine MAF eligibility in addition to the LDSS offices spread the MAF caseload across more workers, which improved the likelihood of timely determinations. It also enabled families who desired food or cash assistance to continue to jointly apply for those benefits through the LDSS. Additionally, it offered a compromise in the internal political struggle over responsibility for eligibility determinations.

\section{Discussion and Conclusion}

Tracing the process through which the Maryland Medicaid program reduced and assumed many supply-side administrative burdens while implementing what was to be a stand-alone increase in the income standard for families enabled the researcher to construct a rich empirical-driven, theory-informed theoretical framework to explain the organizational determinants of administrative burden. In sum, changes in administrative burden are the outcomes of the dynamic interplay of formal policy, the political economy of a public program, various capacities, and formal and informal practices at the management and street-levels, as well as of demand-side causes outside the scope of this article. 
Figure 2 depicts the three-dimensional, multi-directional framework. All changes to administrative burden are shaped by the broader formal policy context, meaning that they build upon and are bounded by existing policies. For example, civil rights statutes and common law bound changes to Medicaid eligibility policy. Changes to administrative burden take place inside a public program, a setting represented by the outside layer of the sphere, which, in even the smallest cases, is an intergovernmental, interdepartmental, and intersectoral organization consisting of the lead program bureau and its partners, which has established patterns and routines. Established patterns include the exercise of authority, such as the federal Medicaid government's authority to approve changes to state Medicaid programs, or the wielding of political power. Formal policy and the political economy determine the economic, human resource, and technological capacities of the program, as well as the implementation timeframe. The more compressed the implementation period, the less able implementers will be to deconstruct a policy legacy. The middle layer of the sphere is program management, which will typically consist of many hierarchical levels. In addition to participating in the political economy, program managers participate in bureaucratic politics (Allison, 1969) and engage with the policy community whose members work to shape implementation in their interests using legal and illegal modes of persuasion. Program managers use various tools and practices to meet policy and program objectives. Street-level practice takes place below the management level. Coping strategies developed by street-level bureaucrats add to the policy legacy, sometimes shaping the program information architecture.

Figure 2

Organizational Determinants of Administrative Burden

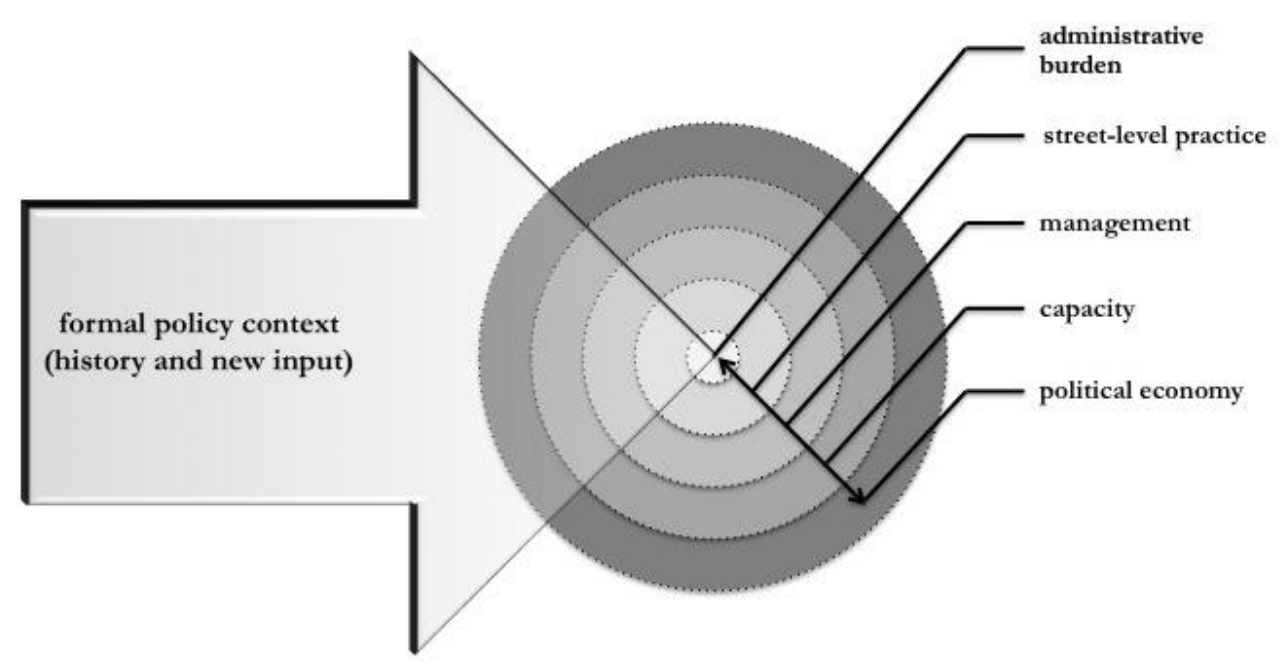


In the State of Maryland, repealed federal Medicaid policy provisions that had once linked Medicaid and welfare eligibility determinations continued to bind DHMH and DHR in practice because LDSS workers determined Medicaid eligibility for families using DHR's automated eligibility system. This policy legacy forced the departments to work together to implement a newly enacted formal policy by an ambitious deadline. A contemporaneous economic crisis drained implementation resources. Stakeholders, including community advocates, lobbied at the political and management levels to adjust implementation in their favor. Within this environment, program directors and managers maneuvered for resources and their preferred implementation approaches. They also devised strategies to keep frontline employees motivated to achieve the policy goal that was a high political priority. As a result of these conditions and dynamics, the state greatly reduced the administrative burdens it imposed on residents.

Responding to calls for positive public administration research (Douglas et al., 2019) and research into the behavioral implications of administrative burdens, as well as requests by health policy research knowledge users for tangible, actionable findings (Radomski \& Smith, 2015 p. 9), this novel case study of the implementation of MAF advanced behavioral public administration theory and produced tools for analyzing the mechanisms of administrative burden that can be useful to theorists, policymakers, and practitioners.

For policymakers intending to design explicit policies to reduce burdens in public benefit programs, the table of administrative burden types (Appendix B) and the model showing how they are typically arranged (Figure 1) provide actionable knowledge for decision-making and planning. Consistent with the configurational thinking that underlies the causal-process tracing approach of this single within-case study (Blatter \& Haverland, 2014, p. 7), the theoretical framework (Figure 2) depicting the organizational determinants of administrative burden, which represents micro, meso, and macro conditions and the interplay between them (Douglas et al., 2019 , p. 7), contributes to the debate on which causal pathways and configurations make reduction of administrative burden possible; therefore, it meets the requirements of policy research, which must allow for " states' unique political environments, budget constraints, and other contextual factors" (Radomski \& Smith, 2015, p. $9)$ and "include at least all of the variables that account for a significant degree of variance in the phenomenon that the policy aims to change" (Etzioni, 2008, pp. 838-839). By depicting all of the potential causes of administrative burden and their interrelationship, the framework is not limited or biased by any ex-post rationalization by the reflexive researcher-participant observer (Blatter \& Haverland, 2014, p. 11). For administrators and public managers, the framework can serve as a high-level roadmap (American Public Human Services Association, 2017, p. 16) for implementing policy or procedure to reduce or shift administrative burdens. By using the framework in implementation simulations practitioners might be able to prevent the introduction of administrative burden via hidden politics (Moynihan, Herd, \& Rigby, 2016; Herd \& Moynihan, 2018).

\section{Notes}

1. The Affordable Care Act eliminated many of the most burdensome application and enrollment requirements for certain Medicaid eligibility groups, namely non-disabled families and children. It did not, however, remove burdens for individuals who qualify on the basis of age or disability.

2. While the researcher was also the lead implementer, the researcher narrates the case in the third person.

3. After completing a second term as governor, O'Malley ran in the Democratic Party's 2016 presidential primary.

4. The Department of Health and Mental Hygiene was later renamed the Maryland Department of Health.

5. The Department of Human Resources was later renamed the Maryland Department of Human Services (DHS).

6. After the Secretary of DHMH appealed to the governor's office, DHR made MAF a higher priority and eventually completed programming in sufficient time to allow implementation to proceed on schedule.

7. The Maryland state legislature (the General Assembly) meets in regular session for 90 days each calendar year beginning in mid-January.

8. DHR (now DHS) is responsible for administering the Supplemental Nutrition Assistance Program (SNAP) in Maryland. LDSS caseworkers determine eligibility for SNAP for which, unlike for Medicaid eligibility determinations, DHR receives 100 percent federal reimbursement. 


\section{References}

Allison, G. T. (1969). Conceptual models and the Cuban missile crisis. The American Political Science Review. 63(3), 689-718.

American Public Human Services Association. (2017). Strategic playbook: Guiding our work for 2018-2022. Washington, D.C.: American Public Human Services Association.

Baker, M. (2020, May 22). Feds suspect vast fraud network is targeting US unemployment systems. The New York Times. Retrieved from: https://www.nytimes.com/2020/05/16/us/coronavirus-unemployment-fraud-secret-service-washington.html

Bartels, K. P. R. (2012). The actionable researcher. Administrative Theory \& Praxis, 34(3), 433-455. doi: 10.2753/ATP1084-1806340306

Barzelay, M. (2007). Learning from second-hand experience: Methodology for extrapolation-oriented case research. Governance: An International Journal of Policy, Administration, and Institutions, 20(3), 521-543.

Beach, D., \& Pedersen, R. B. (2013). Process-tracing methods: Foundations and guidelines. Ann Arbor, MI: The University of Michigan Press.

Blatter, J., \& and Haverland, M. (2014). Case studies and (causal-) process tracing. In I. Engeli, \& C. Rothmayr (Eds.), Comparative Policy Studies. Conceptual and Methodological Challenges (pp. 59-84). London: Palgrave Macmillan.

Bozeman, B. (1993). A theory of government "red tape." Journal of Public Administration Research and Theory, 3, 273-303.

Brodkin, E. Z., \& Majmundar, M. (2010). Administrative exclusion: Organizations and the hidden costs of welfare claiming. Journal of Public Administration Research and Theory, 20(4), 827-848. doi: 10.1093/jopart/mup046

Burden, B. C., Canon, D. T., Mayer, K. R., \& Moynihan, D. P. (2012). The effect of administrative burden on bureaucratic perception of policies: Evidence from election administration. Public Administration Review, 72(5), 741-751.

Cohen Ross, D., Horn, A. \& Marks, C. (2008). Health coverage for children and families in Medicaid and SCHIP: State efforts face new hurdles. Retrieved from https://www.kff.org/medicaid/report/ health-coverage-for-children-and-families-in/

Cohen Ross, D., \& Marks, C. (2009). Challenges of providing health coverage for children and parents in a recession: A 50 state update on eligibility rules, enrollment and renewal procedures, and cost-sharing practices in Medicaid and SCHIP in 2009. Retrieved from https://www.kff.org/wp-content/uploads/2013/01/7855.pdf
Douglas, S., Hart, P., Andersen, L., Flinders, M., Head, B., Moynihan, D., \& ... Torfing, J. (2019). Towards positive public administration: A manifesto. Draft Proposal.

Etzioni, A. (2008). The unique methodology of policy research. In R. E. Goodin, M. Moran, \& M. Rein (Eds.), The Oxford handbook of public policy (pp. 833-843). Oxford: Oxford University Press.

Grimmelikhuijsen, S., Jilke, S., Olsen, A. L, \& Tummers, L. (2016). Behavioral public administration: Combining insights from public administration and psychology. Public Administration Review, 77(1), 45-56.

Guest, G., Namey, E. E., \& Mitchell, M. L. (2013). Collecting qualitative data. London, UK: Sage Publications, Ltd.

Heinrich, C. J. (2016). The bite of administrative burden: A theoretical and empirical investigation. Journal of Public Administration Research and Theory, 26, 403-420.

Herd, P., DeLeire, T., Harvey, H., \& Moynihan, D. P. (2013). Shifting administrative burden to the state: The case of Medicaid take-up. Public Administration Review, 73, S69-S81.

Herd, P., \& Moynihan, D. P. (2018). Administrative burden: Policymaking by other means. New York, NY: Russell Sage Foundation.

Herd, P., \& Moynihan, D. P. (2020, April 13). The coronavirus stimulus is playing hard to get. The New York Times. Retrieved from: https://www.nytimes.com/2020/04/13/opinion/coronavirus-stimulus-relief.html

Hernanz, V., Malherbet, F., \& Pellizzari, M. (2004). Takeup of welfare benefits in OECD countries: A review of the evidence. Social, Employment and Migration Working Paper no. 17, Organisation for Economic Co-operation and Development.

http://www.oecd.org/els/soc/30901173.pdf [accessed July 16, 2013].

Kim, K. (2017). Challenges of observational and retrospective studies [PowerPoint slides]. Retrieved from https://health.ucdavis.edu/ctsc/area/Resource_Library/documents/Challenges $\% 20$ of $\% 20$ Retrospective $\% 20$ Observational $\% 20$ Studies_8March2017_Kim.pdf

Klarner, C., Mao, X., \& Buchanan, S. (2007). Business interest groups and temporary assistance to needy families. Social Science Quarterly, 88, 104-119.

Lipsky, M. (1984). Bureaucratic disentitlement in social welfare programs. Social Science Review, 58, 3-27.

Maryland State Archives. (2020a, June 12). Maryland Department of Health. Maryland manual online. https://msa.maryland.gov/msa/mdmanual/16dhmh/html/dhmh.html 
Maryland State Archives. (2020b, June 12). Maryland De partment of Human Services. Maryland manual online.

Maryland State Archives. (2020c, June 12). Local government. Maryland manual online.https://msa.maryland.gov/msa/mdmanual/01glance/html/county.html

McGreevey, P., \& Christensen, K. (2020, April 27). Californians battling unemployment amid coronavirus are stymied by state agency's tech issues. Los Angeles Times. Retrieved from: https://www.latimes.com/california/story/202004-27/coronavirus-california-unemployment-insurance-claims-technology-issues-edd

Moynihan, D. P., Herd, P., \& Harvey, H. (2014). Administrative burden: Learning, psychological, and compliance costs in citizen-state interactions. Journal of Public Administration Research and Theory, 25, 43-69.

Moynihan, D. P., Herd, P., \& Ribgy, E. (2016). Policymaking by other means: Do states use administrative barriers to limit access to Medicaid? Administration \& Society, 48, 497-524.

Peeters, R. (2020). The political economy of administrative burdens: A theoretical framework for analyzing the organizational origins of administrative burdens. Administration \& Society, 52(4), 566-592.

Piven, F. F., \& Cloward, R. A. (1971). Regulating the Poor. New York, NY: Vintage Books.

Pressgrove, J. (2020, May 27). Staffing issues complicate unemployment agency tech woes. Government Technology. Retrieved from: https://www.governing.com/work/Staffing-Issues-Complicate-Unemployment-Agency-Tech-Woes.html

Radomski L, \& Smith S. (2015). The Academy Health listening project: Improving the evidence base for Medicaid policymaking.

Ravenell, N. (Ed.). (2003). The burden of proof: How much is too much for health care coverage? (2nd ed.). Columbia, SC: Southern Institute on Children and Families.
Robert Wood Johnson Foundation. (2020). Grants explorer. Rury, J.L (2014). The power and limitations of historical case study: A consideration of postwar African American educational experience. Social and Education History 3(3), 241-270. doi:10.4471/hse.2014.15

Sharfstein, S. S., Peterson, R. R., Brown, P. M. C., Katz, B., Brown, N., Lindamood, M., \& Luckner, M. (2007, February 9). Report to the new secretary, Maryland Department of Health and Mental Hygiene. O'Malley/Brown Transition, Department of Health and Mental Hygiene Working Group, Baltimore, MD. https://msa.maryland.gov/megafile/msa/spec$\mathrm{col} / \mathrm{sc} 5300 / \mathrm{sc} 5339 / 000113 / 003000 / 003316 /$ unrestricted/20070088e.pdf

Smeeding, T. (2019). Book review. [Review of the book Administrative burden: Policymaking by other means, by P. Herd \& D. P. Moynihan]. Journal of Policy Analysis and Management, 38(4), 1077-1082.

Soss, J., Schram, S., Vartanian, T., \& O'Brien, E. (2001). Setting the terms of relief: Explaining state policy choices in the devolution revolution. American Journal of Political Science, 45(2), 378-395.

Tummers, L. L. G., Bekkers, V., Vink, E., \& Musheno, M. (2015). Coping during public service delivery: A conceptualization and systematic review of the literature. Journal of Public Administration Research and Theory, 25, 1099-1126.

Wagner, J. (2007, October 7). Session would be risky for O'Malley. The Washington Post. Retrieved from: https://www.washingtonpost.com/wp-dyn/content/article/2007/10/06/AR2007100601324.html

Weber, M. (1946). From Max Weber: Essays in sociology. In H. H. Gerth, \& C. Wright Mills (Eds.), Oxford, UK: Oxford University Press, Inc.

Working Families and Small Business Health Coverage Act, Md. Assemb. B. 6 (2007), Chapter 7 (Md. Stat. 2007).

Yin, R. K. (2009). Case Study Research: Design and Methods (4thed.). Thousand Oaks, California: Sage Inc. 


\section{Appendix}

\section{Appendix A. Actions to Reduce or Shift Administrative Burden Subsequent to MAF Enactment}

\begin{tabular}{|l|l|}
\hline $\begin{array}{l}\text { Type of } \\
\text { Burden }\end{array}$ & Action \\
\hline $\begin{array}{l}\text { Information } \\
\text { barriers }\end{array}$ & Conducted outreach to potentially eligible individuals identified through tax returns \\
\hline Categorical & $\begin{array}{l}\text { Auto-enrolled beneficiaries who had been receiving limited benefits (through the } \\
\text { medically needy category and Primary Adult Care program) }\end{array}$ \\
\hline $\begin{array}{l}\text { Application } \\
\text { processes }\end{array}$ & Developed a Medicaid-only application \\
\hline $\begin{array}{l}\text { Application } \\
\text { processes }\end{array}$ & $\begin{array}{l}\text { Allowed all Medicaid eligibility offices-LDSS and local health departments (LHDs)- } \\
\text { to process the Medicaid-only application }\end{array}$ \\
\hline $\begin{array}{l}\text { Application } \\
\text { processes }\end{array}$ & Held a process improvement collaborative with caseworkers from all eligibility offices \\
\hline $\begin{array}{l}\text { Application } \\
\text { processes }\end{array}$ & Performed intensive in-county training of every caseworker \\
\hline $\begin{array}{l}\text { Application } \\
\text { requirements }\end{array}$ & Eliminated the face-to-face interview requirement \\
\hline $\begin{array}{l}\text { Application } \\
\text { requirements }\end{array}$ & Eliminated certain verification requirements \\
\hline Asset testing & Eliminated the asset test \\
\hline $\begin{array}{l}\text { Renewal } \\
\text { requirements }\end{array}$ & Simplified forms \\
\hline
\end{tabular}




\section{Appendix B. Types of Administrative Burden in Public Benefit Programs}

\begin{tabular}{|l|l|}
\hline Type & Nature \\
\hline $\begin{array}{l}\text { Information } \\
\text { barriers }\end{array}$ & $\begin{array}{l}\text { Difficult to access sufficient clear official information about eligibility, benefits, and/or } \\
\text { the application and enrollment process via the Internet, phone, or in-person contact. }\end{array}$ \\
\hline $\begin{array}{l}\text { Categorical } \\
\text { requirements }\end{array}$ & $\begin{array}{l}\text { Individuals must fit into categories based on age, family composition, or other } \\
\text { characteristics in order to be eligible for services or benefits. }\end{array}$ \\
\hline $\begin{array}{l}\text { Benefit } \\
\text { conditions }\end{array}$ & $\begin{array}{l}\text { Eligible individuals must satisfy conditions, such as looking for work, in order to receive } \\
\text { benefits. }\end{array}$ \\
\hline $\begin{array}{l}\text { Application } \\
\text { processes }\end{array}$ & $\begin{array}{l}\text { Paper applications are difficult to acquire, read, and/or complete due to design, length, } \\
\text { literacy level, and/or insufficient translations. Electronic applications are difficult to ac- } \\
\text { cess due to hardware and/or software requirements, lack of connectivity, limited band- } \\
\text { width, and/or poor computer skills. Application processing times are lengthy. }\end{array}$ \\
\hline $\begin{array}{l}\text { Application } \\
\text { requirements }\end{array}$ & $\begin{array}{l}\text { Applicants are subject to waiting periods and/or must give interviews and/or provide } \\
\text { proof of age, identify, citizenship or immigration status, income, assets, and/or other } \\
\text { characteristics in order to receive a determination of eligibility for services or benefits. }\end{array}$ \\
\hline $\begin{array}{l}\text { Income } \\
\text { testing }\end{array}$ & $\begin{array}{l}\text { To be eligible for services or benefits an application unit's income must not exceed a } \\
\text { specified level. }\end{array}$ \\
\hline Asset testing & $\begin{array}{l}\text { To be eligible for services or benefits an application unit's assets must not exceed a } \\
\text { specified level. }\end{array}$ \\
\hline $\begin{array}{l}\text { Continuing } \\
\text { eligibility } \\
\text { requirments }\end{array}$ & $\begin{array}{l}\text { Beneficiaries must meet ongoing requirements, such as performing regular work, in } \\
\text { order to remain eligible for services or benefits. }\end{array}$ \\
\hline $\begin{array}{l}\text { Renewal } \\
\text { requirements }\end{array}$ & $\begin{array}{l}\text { Beneficiaries must take steps, such as completing forms or reports, at pre-specified } \\
\text { intervals in order to renew their eligibility for services or benefits. }\end{array}$ \\
\hline
\end{tabular}

